\title{
Urgensi Akta Notaris Dalam Perikatan Kerja Antara Kantor Jasa Penilai Publik dengan Perusahaan Emiten Terhadap Implikasi Penilaiannya di Bursa Saham
}

\author{
Lazuardi Ardiman, Iwan Permadi, Bambang Winarno \\ Fakultas Hukum Universitas Brawijaya \\ lazuardi_ardiman@yahoo.com
}

\begin{abstract}
This journal aims to examine whether the notary deed has the urgency of a working alliance between the Assessor's Public Services with Corporate Issuers, particularly those which can have implications for against the stock exchange. This type of research is the normative legal based Article 1233 of the Book Law Civil Law about the Alliance, 1870 Article Book of Law Civil Law about the Authentic Act, law No. 8 year 1995 Regarding Capital Market, Act No. 21 of the year 2011 About The Financial Services Authority and Act No. 2 by 2014 About Changes in The Law No. 30 of 2004 Concerning of Notary Public, as well as assisted with other legal materials outlined, is described and analyzed linkages with each other. From the results of this study, answered that the Notary Deed is an essential thing in make the Alliance between the Assessor's Public Services with Corporate Issuers, because both sides have a legal responsibility to public especially who became investors in the stock exchange, against transparency, competence and good business prospects. Another reason is because the regulations are there for there has been no explicit specify the form of the working relationship between the parties.
\end{abstract}

Keywords: Notary Deed, Alliance, Legal Certainty.

\section{Abstrak}

Artikel ini bertujuan untuk mengkaji apakah Akta Notaris memiliki urgensi yang utama dalam perikatan kerja antara Kantor Jasa Penilai Publik dengan Perusahaan Emiten, terutama yang dapat berimplikasi terhadap bursa saham. Jenis penelitian ini adalah hukum normatif (Normative Legal Research) berdasar Pasal 1233 Kitab Undang-Undang Hukum Perdata tentang perikatan, Pasal 1870 Kitab Undang-Undang Hukum Perdata tentang Akta Autentik, Undang-Undang Nomor 8 Tahun 1995 Tentang Pasar Modal, Undang-Undang Nomor 21 Tahun 2011 Tentang Otoritas Jasa Keuangan dan Undang-Undang Nomor 2 Tahun 2014 Tentang Perubahan Atas Undang-Undang Nomor 30 Tahun 2004 Tentang Jabatan Notaris, serta dibantu dengan bahan-bahan hukum lain yang diuraikan, dideskripsikan dan dianalis keterkaitan satu sama lain. Dari hasil penelitian ini terjawab bahwa Akta Notaris merupakan Akta yang penting untuk di buat dalam perikatan kerja antara Kantor Jasa Penilai Publik dengan Perusahaan Emiten, karena kedua belah pihak memiliki tanggung jawab hukum terhadap masyarakat luas (public) khususnya yang menjadi investor di bursa saham, terhadap transparansi, kompetensi, dan prospek bisnis yang baik. Alasan lain adalah karena 
dari peraturan-peraturan yang ada tidak ada yang secara eksplisit menentukan bentuk hubungan kerja antara para pihak.

\section{Kata kunci: Akta Notaris, Perikatan, Kepastian Hukum.}

Pendahuluan

Dengan diterbitkannya UndangUndang Nomer 8 Tahun 1995 Tentang Pasar Modal (selanjutnya disebut UUPM), dalam konsiderannya dapat dilihat bahwa pemerintah memandang perlu untuk mencapai tujuan pembangunan nasional dan terciptanya suatu masyarakat adil dan makmur berdasarkan Pancasila dan UndangUndang Dasar 1945, bahwa Pasar Modal dipandang memiliki peran yang strategis dalam pembangunan nasional sebagai salah satu sumber pembiayaan bagi dunia usaha. Pasar modal memerlukan landasan hukum yang kuat untuk menjamin kepastian hukum pihak-pihak yang melakukan kegiatan di pasar modal serta melindungi kepentingan masyarakat pemodal dari praktik yang merugikan.

Pada dasarnya pasar modal adalah tempat diperjualbelikannya berbagai instrumen keuangan jangka panjang, seperti utang, ekuitas (saham), instrument derivatif dan lainnya, pasar modal merupakan sarana pendanaan bagi perusahaan maupun institusi lainnya dan juga merupakan sarana berinvestasi, dengan adanya pasar modal aktifitas perekonomian diharapkan meningkat, karena pasar modal merupakan alternatif pendanaan bagi perusahaan, sehingga perusahaan dapat beroperasi dengan skala yang lebih besar dalam meningkatkan pendapatan perusahaan (Darmadji dan Fakhruddin,2012:1-2) .

Dengan UUPM, Pemerintah berupaya untuk mendorong kemajuan pasar modal yang sehat, transparan dan efisien, maka salah satu persyaratan yang ditetapkan pemerintah bagi perusahan yang ingin menjadi perusahaan publik dengan menjual sahamnya untuk memperoleh pendanaan dari masyarakat luas adalah dengan melalui proses penilaian sebelum saham-sahamnya dijual di bursa saham,dan merubah bentuk 
perusahaan tersebut menjadi perusahaan umum atau publik yang terbuka (Tbk). Berdasarkan UndangUndang Nomor 21 Tahun 2011 Tentang Otoritas Jasa Keuangan (selanjutnya disebut UUOJK) disebutkan bahwa Otoritas Jasa Keuangan (selanjutnya disebut OJK) adalah lembaga yang independen dan bebas dari campur tangan pihak lain, yang mempunyai fungsi, tugas, dan wewenang pengaturan, pengawasan, pemeriksaan, dan penyidikan sebagaimana dimaksud dalam Undang-Undang. Salah fungsi dan tugas pokok OJK adalah dibidang pengawasan sektor pasar modal dengan tugas sebagai penyelenggara sistem pengaturan dan pengawasan yang terintegrasi terhadap keseluruhan kegiatan di sektor jasa keuangan.

Sebagai bentuk tercapainya transparansi dan guna memberikan perlindungan kepada investor serta masyarakat luas, maka OJK mengeluarkan aturan-aturan tentang perlunya untuk memberikan nilai dari harga saham tersebut yang salah satunya dapat bersumber dari hasil penilaian asset yang dilakukan oleh
Profesi Penilai (selanjutnya disebut Penilai) yang tergabung di Kantor Jasa Penilai Publik (selanjutnya disebut KJPP) yang telah mendapat persetujuan dan izin dari Menteri Keuangan, berdasarkan ketentuanketentuan di terbitkan oleh Pemerintah.

Dalam Pasal 64 UUPM, disebutkan bahwa Penilai adalah salah satu Profesi Penunjang Pasar Modal, yang bertugas untuk membantu sebuah perusahaan yang akan menjadi emiten atau perusahaan penerbit saham di bursa, didalam masa persiapan penerbitan surat berharga di pasar modal, dalam bentuk emisi atau saham. Sebagai salah satu profesi penunjang pasar modal, Penilai dan profesi penunjang lainnya turut bertanggung jawab dalam mengembangkan pasar modal dan membantu emiten dalam proses go public.

Penilai wajib memiliki pengetahuan yang baik tentang pasar modal serta aturan-aturan yang melandasinya, dan secara aktif memberikan nasehat kepada Emiten untuk terus memenuhi aturan yang berlaku.Integritas, profesionalisme 
dan independensi Penilai menjadi sangat penting bagi tujuan keterbukaan Pasar Modal.Profesi Penilai mulai dibutuhkan sejak Badan Pengawas Pasar ModalLembaga Keuangan (Bapepam-LK) yang sekarang menjadi OJK, melakukan pembatasan kegiatan penilaian bisnis di pasar modal pada tahun 2006 lalu, yang menentukan bahwa yang kompeten melakukan praktek penilaian bisnis adalah Penilai, khususnya Penilai yang terdaftar di pasar modal. Dengan dikeluarkannya peraturan Menteri Keuangan Nomor 125/PMK.01/2008 Tanggal 3 September 2008 Tentang Jasa Penilai Publik disebutkan yang berkewajiban melakukan penilaian adalah Penilai Publik yang bernaung dalam KJPP, sejak adanya aturan ini kebutuhan akan jasa penilai bisnis semakin terdorong maju.

Profesi Penilai adalah suatu bidang keahlian yang mempunyai kemampuan dan tugas pelayanan jasa dengan standarisasi khusus serta kompetensi bidangnya dan dengan adanya kode etik profesi sebagai panduan dalam melaksanakan pelayananya kepada masyarakat. Dalam proses penerbitan saham atau obligasi, Emiten wajib mencari profesi penunjang untuk membantu menyiapkan dokumen, yaitu Akuntan Publik untuk melakukan audit atas laporan keuangan, Notaris untuk melakukan perubahan atas anggaran dasar, membuat akta perjanjian-perjanjian dalam rangka penawaran umum dan juga notulennotulen rapat dan Konsultan Hukum untuk memberikan pendapat dari segi hukum (legal opinion) (Rusdin,2006:89). Sedangkan tugas Penilai membantu proses evaluasi utama dari terbitnya emisi, dan aspek lain untuk melindungi kepentingan pemodal dalam rangka keterbukaan Emiten. Maka Emiten wajib memberikan dokumen-dokumen yang salah satunya adalah laporan dari Penilai, dan apabila Emiten melakukan revaluasi terhadap aktiva tetapnya, maka penilaian harus dilakukan kembali oleh Penilai yang independen, serta pernyataan mengenai hasil penilaian aktiva tetap tersebut harus di laporkan oleh Penilai dalam sebuah laporan resmi 
yang disampaikan kepada OJK (Rusdin,2006:89).

Proses tersebut penting bagi terwujudnya kemajuan ekonomi nasional dari sektor pasar modal di bursa saham, proses ini juga mampu mewujudkan transparansi guna memberikan perlindungan kepada investor serta masyarakat luas. Peran Penilai menjadi penting bagi proses terbitnya suatu emisi guna menentukan nilai wajar berdasar asset perusahaan yang besangkutan, berapa nilai pertambahan dan penyusutannya, karena hasil ini diperlukan oleh investor dalam mengambil keputusan investasinya (Tavinayati,2009:36-37).

Berdasarkan hasil bahan hukum, hubungan antara Perusahaan Emiten dan Profesi Penilai sebagai Profesi Penunjang Pasar Modal tidak tergambarkan secara jelas berkaitan dengan perikatan yang mereka buat selama ini, baik berdasar peraturan perundang-undangan maupun aturan OJK. Peraturan OJK tidak ada yang secara eksplisit mengatur tata cara hubungan dan perikatan yang harusnya dibuat antara kedua belah pihak tersebut.
Perikatan yang mereka buat selama ini berbentuk perikatan di bawah tangan, karena belum adanya aturan hukum yang jelas dan tegas mengatur hubungan kerja antara kedua belah pihak, sehingga hak dan kewajiban yang ada menjadi sangat relatif berdasarkan maksud dan tujuan masing-masing pihak, yang artinya menjadi perikatan yang ada ini lahir karena perjanjian, bukan karena Undang-Undang.

Berdasarkan dengan rumusan Pasal 1233 Kitab Undang-Undang Hukum Perdata (selanjutnya disebut KUHPerdata), dinyatakan bahwa tiap-tiap perikatan dilahirkan baik karena persetujuan, baik karena Undang-Undang Muljadi dan Widjaja,2014:3). Perbedaan antara perikatan yang lahir karena perjanjian dan yang lahir karena Undang-Undang adalah pada hak dan kewajiban para pihaknya, jika dalam perjanjian yang lahir karena perjanjian berdasarkan kemauan dan kehendak sendiri dari para pihak yang bersangkutan, sedangkan perikatan yang lahir karena UndangUndang bukan berdasarkan kehendak para pihak, melainkan telah diatur 
dan ditentukan oleh Undang-Undang (R.Soeroso, 2011:5). Dalam kajian ini sudah seharusnya perikatan antara Emiten dan Penilai mengacu kembali kepada Undang-Undang, yaitu UUPM dan peraturan-peratutan lain termasuk peraturan OJK, karena kedua belah pihak itu dipertemukan oleh peraturan-peraturan dimaksud dan bukan oleh kehendak masingmasing pihak belaka.

Perjanjian yang dibuat menjadi akta oleh kedua belah pihak, Akta adalah suatu penyataan tertulis yang ditandatangani dibuat oleh seseorang atau lebih pihak-pihak dengan maksud dapat digunakan sebagai alat bukti dalam proses hukum, dan sebagai alat bukti tertulis maka perjanjian tersebut berbentuk surat yang merupakan akta atau bukan akta berdasarkan anatominya, sedangkan akta sendiri dibagi menjadi akta autentik dan akta dibawah tangan .

Akta Autentik adalah suatu akta yang bentuknya ditentukan oleh Undang-Undang, dibuat oleh atau dihadapan pejabat umum yang berwenang untuk itu,ditempat dimana akta itu dibuat, sesuai dengan makna dari Pasal 1868 KUHPerdata. Keistimewaan Akta Autentik adalah merupakan alat bukti yang sempurna, sesuai Pasal 1870 KUHPerdata, artinya sempurna karena merupakan bukti yang sempurna sehingga tidak perlu lagi dibuktikan dengan pembuktian lain selama ketidakbenarannya tidak dapat dibuktikan. Sedangkan Akta Dibawah Tangan dibuat tidak oleh atau tanpa pejabat umum, melainkan dibuat dan ditandatangani sendiri oleh para pihak yang mengadakan perjanjian dan selama para pihak tidak menyangkal isi dan apa yang ditulis dalam perjanjian itu, maka akta dibawah tangan tersebut mempunyai kekuatan pembuktian yang sama dengan Akta Autentik .

Maka berdasarakan hal tersebut serta memperhatikan pentingnya fungsi dan tugas KJPP dan Perusahaan Emiten kepada masyarakat dan investor serta dampak yang luas dari penetapan nilai emisi yang akan dijual di bursa saham, juga berdasarkan informasi yang penulis kumpulkan diawal survey kepada dua KJPP terhadap bentuk-bentuk perikatan dan akta 
yang ada, maka penulis menemukan rumusan masalah sebagai berikut : 1) Bagaimana keberlakuan akta dalam perikatan kerja antara KJPP dengan Perusahaan Emiten, 2) Bagaimana urgensi Akta Notaris dalam perikatan kerja antara KJPP dengan Perusahaan Emiten, 3) Bagaimana akibat hukum yang timbul dari Akta Notaris sebagai perikatan kerja antara KJPP dengan Perusahaan Emiten.

Penelitian ini merupakan penelitian hukum normatif, yang merupakan kegiatan know-how dalam ilmu hukum, bukan sekedar know-about, penelitian hukum dilakukan untuk memecahkan permasalahan hukum yang dipilih, dengan mengidentifikasi masalah hukum, melakukan penalaran hukum, menganalisis masalah yang dihadapi dan kemudian memberikan pemecahan atas masalah tersebut (Marzuki,2014:60). Penelitian ini berisi tentang kajian dari sistematika hukum yang mendasari perikatan kerja antara KJPP dengan Perusahaan Emiten yang bertujuan mengidentifikasi terhadap pengertian dasar hak dan kewajiban, peristiwa hukum, hubungan hukum dan obyek hukumnya, serta makna tentang Akta Notaris sebagai Akta Autentik dalam perikatan. Penelitian ini juga untuk mengetahui taraf sinkronisasi hukum positif yang relevan di KUHPerdata, UUPM, UUOJK, Undang-Undang Nomor 2 Tahun 2014 Tentang Perubahan Atas Undang-Undang Nomor 30 Tahun 2004 Tentang Jabatan Notaris, serta peraturan lain yang berkaitan dengan pasar modal.

Pendekatan yang digunakan dalam penelitian ini adalah pendekatan perundang-undangan (statue approach) dan pendekatan kasus (case approach). Pendekatan undang-undang yang dilakukan dengan menelaah semua UndangUndang dan regulasi yang bersangkutan dengan issue hukum diketengahkan (Susanti dan Effendi,2013:110). Pendekatan perundang-undangan sangat berguna karena memberikan kesempatan kepada peneliti untuk mempelajari konsistensi dan kesesuaian antara peraturan perundang-undangan yang ada (Marzuki,2014:93).

Pendekatan kasus adalah metode yang dapat dipergunakan oleh 
peneliti karena adanya kekosongan hukum atau kekaburan norma dalam penerapannya (Diantha, 2016:165), dengan mengkaji peraturan hukum yang berkaitan dengan perikatan antara KJPP dan Perusahaan Emiten dalam penilaian menuju persiapan $g o$ public. Bentuk perikatan yang ada dilapangan secara nyata dikorelasikan dengan dampaknya secara hukum dan hasil penilaian tersebut di bursa saham, metode ini diharapkan dapat melihat kendalakendala yang dapat mengakibatkan kerugian diantara para pihak, menemukan hak dan kewajiban yang seharusnya bagi para pihak atau bahkan menemukan kemungkinan adanya potensi kerugian masyarakat secara umum sebagai investor, dengan mencari bagaimana mendapatkan peraturan hukum yang dapat menjadi payung hukum dari fakta-fakta dilapangan.

\section{Pembahasan}

Keberlakuan Akta Dalam Perikatan Kerja Antara Kantor Jasa Penilai Publik dengan Perusahaan Emiten.

Berdasarkan hasil penelitian yang telah diperoleh, maka dapat dianalisa bahwa perikatan yang dibuat oleh Penilai dengan Perusahaan Emiten yang ada dan lazim dipergunakan adalah akta di bawah tangan. Perusahaan Emiten akanmemilih Penilai yang tergabung di KJPP yang telah terdaftar sebagai rekanan di OJK. KJPP terpilih akan diminta Perusahaan Emiten untuk membuat rencana kerja tentang penilaian dari aspek-aspek yang di perlukan, berikut KJPP akan membuat rincian pengajuan biaya dan termin-termin pekerjaan serta pembayaran jasa penilaian.

Dalam penelitian ini salah satu aspek teori yang digunakan adalah teori perjanjian, eksistensi perjanjian sebagai salah satu sumber perikatan dapat dilihat dalam ketentuan Pasal 1233 KUHPerdata yang menyebutkan bahwa perikatan dapat dilahirkan karena perjanjian ataupun undang-undang. Hal ini dipertegas lagi dengan rumusan ketentuan Pasal 1313 KUHPerdata yang menyatakan bahwa perjanjian adalah perbuatan seseorang atau lebih untuk mengikatkan diri terhadap satu orang atau lebih.Perikatan akan melahirkan hak dan kewajiban bagi yang melakukannya, dengan melakukan 
perjanjian maka pihak yang mengadakan perjanjian tersebut secara sukarela mengikatkan diri untuk meyerahkan sesuatu, berbuat sesuatu atau untuk tidak berbuat sesuatu.

Perbedaan antara perikatan yang bersumber dari perjanjian dan perikatan yang bersumber dari Undang-Undang adalah sebagai berikut :

1) Perikatan yang lahir dari perjanjian;

Menimbulkan hubungan hukum yang memberikan hak dan meletakkan kewajiban kepada para pihak yang membuat perjanjian berdasarkan atas kemauan dan kehendak sendiri dari para pihak yang bersangkutan yang mengikatkan diri.

1) Perikatan yang lahir dari Undang-Undang;

Terjadi karena adanya suatu peristiwa tertentu sehingga melahirkan hubungan hukum yang menimbulkan hak dan kewajiban diantara para pihak yang bersangkutan, tetapi bukan berasal atau merupakan kehendak para pihak, melainkan telah diatur dan ditentukan oleh Undang-Undang.

Berdasarakan analisa bahan hukum dari perikatan yang ada antara Perusahaan Emiten dan KJPP yang dipergunakan adalah akta dibawah tangan karena akta yang dibuat tanpa adanya perantaraan pejabat umum yang berwenang, melainkan dibuat dan ditandatangani sendiri oleh para pihak yang mengadakan perjanjian (Soeroso, 2011:8). Jika di analisa lebih dalam dari bahan hukum yang ada, dari sumber perjanjian antara kedua belah pihak ini seharusnya merupakan perikatan yang lahir karena UndangUndang, karena hubungan diantaranya terjadi karena adanya suatu peristiwa tertentu yaitu upaya untuk melaksanakan go public sehingga melahirkan hubungan hukum yang menimbulkan hak dan kewajiban diantara para pihak yang bersangkutan, tetapi bukan berasal atau merupakan kehendak para pihak itu sendiri, melainkan telah diatur dan ditentukan oleh Undang-Undang (Soeroso,2011:5), termasuk dari UUPM serta UUOJK. 
Gustav Radbruch memberikan kontribusi yang mendasar terhadap teori kepastian hukum, dengan tiga ide dasar hukum yaitu keadilan, kemanfaatan dan kepastian hukum. Kepastian hukum adalah keadaan suatu peraturan dibuat dan diundangkan secara jelas, pasti dan logis, yang dimaksud jelas adalah tidak adanya kekaburan norma atau keraguan sedangkan logis adalah menjadi suatu sistem norma dengan norma yang lain sehingga tidak berbenturan atau menimbulkan konflik norma. Kepastian hukum memberikan pemberlakuan hukum yang jelas, tetap, konsisten dan konsekuen, yang pelaksanaannya tidak dapat dipengaruhi oleh keadaan yang bersifat subyektif.Kepastian hukum dalam suatu negara adalah dengan adanya Undang-Undang yang telah ditentukan dan sungguhsungguh berlaku sebagai hukum, putusan-putusan hakim para hakim yang bersifat konstan, dan berakibat kepada masyarakat yang tidak raguragu terhadap hukum yang berlaku (Radbruch, et al,2006:6). Dari analisa bahan hukum ditemukan bahwa fungsi, tugas dan tanggung jawab Perusahaan Emiten dengan Penilai telah jelas disebutkan, akan tetapi justru interaksi atau keterhubungan antara para pihak tersebut tidak dijelaskan secara eksplisit dalam aturan yang ada, termasuk hubungan hukum dan wujud perikatan yang harusnya mereka buat.

Menurut Jeremmy Bentham (Atre,2011:37), ketidaksempurnaan (imperfection) dapat mempengaruhi peraturan perundang-undangan dan Bentham membagi ketidaksempurnaan itu dalam dua derajat atau tingkatan, yaitu;

1) Ketidaksempurnaan derajat pertama yang disebabkan oleh arti ganda (ambiguity), kekaburan (absurdity/vaguiness) dan terlalu luas (overbulkiness)

2) Ketidaksempurnaan derajat kedua disebabkan oleh ketidaktepatan ungkapan, ketidaktepatan tentang pentingnya sesuatu, berlebihan, terlalu panjang lebar, membingungkan, tanpa tanda yang memudahkan pemahaman, dan ketidakteraturan. 
Hasil analisis menunjukkan bahwa akta yang dipergunakan oleh pihak Emiten dan KJPP adalah akta dibawah tangan yang biasa dipergunakan dari perikatanperikatan yang lahir dari perjanjian, bukan dari UndangUndang.Hubungan kerja yang ada dari kedua belah pihak tidak diatur secara jelas bentuknya dalam peraturan-peraturan yang sudah ada, yang menurut Bentham hal ini telah terjadi kekaburan.

Berdasarkan pendapat Habib Adjie, menurut Pasal 8 ayat (1) Undang-Undang Nomor 12 Tahun 2011 Tentang Pembentukan Peraturan Perundang-Undangan disebutkan atau ditentukan bahwa suatu perbuatan atau tindakan hukum wajib dibuat dalam bentuk Akta Notaris, yang dibuat atau ditetapkan oleh (Adjie,2015:11-12) ; 1) Majelis Permusyawaratan Rakyat, 2) Dewan Perwakilan Rakyat, 3)Dewan Perwakilan Daerah, 4) Mahkamah Agung, 5) Mahkamah Konstitusi, 6)Badan Pemeriksa Keuangan, 7)Komisi Yudisial, 8)Bank Indonesia, 9)Menteri,10) Badan, lembaga, atau komisi yang setingkat yang dibentuk dengan UndangUndang atau Pemerintah atas perintah Undang-Undang, 11)Dewan Perwakilan Rakyat Daerah Provinsi, Gubernur, 12) Dewan Perwakilan Rakyat Daerah Kabupaten/Kota, Bupati/Walikota, 13) Kepala Desa atau yang setingkat.

Pendapat ini menunjukkan wewenang notaris yang semakin penting dalam tindakan hukum yang di tetapkan atau dibuat oleh pihakpihak yang tersebut dalam UndangUndang diatas.Jadi hasil analisis dari pendapat ini menunjukkan pentingnya keberadaan Akta Notaris sebagai kekuatan dan kepastian hukum dari semua produk tindakan hukum, terlebih yang berhubungan dengan lembaga negara yang jelas berdampak kepada kepentingan publik secara luas.

\section{Urgensi Akta Notaris dalam perikatan kerja antara KJPP dengan Perusahaan Emiten.}

Mengacu kepada ketentuan peraturan perundang-undangan, tata cara dan pelaksanaan kegiatan pasar modal secara umum dari UUPM dan peraturan-peraturan pelaksanaannya, serta UUOJK, walaupun tidak 
disebutkan secara jelas tentang tata cara pelaksanaan hubungan kerja antara Perusahaan Emiten dengan KJPP, namun pada kenyataannya dari hasil bahan hukum ditemukan bahwa hubungan kerja diantaranya senantiasa dibuat dengan akta dibawah tangan. Hal ini akan sangat rentan terjadi permasalahanpermasalahan hukum jika salah satu diantaranya menyatakan tidak mengakui sebagian atau keseluruhan isi akta tersebut. Dalam pasal 103 sampai 111 UUPM ditegaskan tentang fungsi, tugas dan wewenang masing-masing pihak, serta diatur adanya sanksi pidana dan ganti rugi secara perdata, jika terbukti salah satu atau semua pihak terkait dengan pasar modal menyebabkan kerugian kepada masyarakat.

Berdasar Undang-Undang dimaksud serta peraturan-peraturan lain sebagai pelaksanaannya posisi Profesi Penilai yang tergabung dalam KJPP, ketentuan Peraturan Menteri Keuangan Nomor 125/PMK.01/2008, dalam Pasal 15 ayat (1) disebutkan bahwa badan usaha profesi penilai adalah dalam KJPP yang dapat berbentuk perorangan atau persekutuan. Dalam Pasal 14 ayat (3) disebutkan bahwa KJPP bentuknya adalah persekutuan atau firma. Ketentuan ini merubah ketentuan sebelumnya tentang profesi penilai yang berbentuk Perseroan Terbatas yang otomatis tunduk kepada Undang-Undang Perseroan Terbatas dengan tanggung jawab profesi penilai yang sebelumnya terbatas menjadi mengikuti peraturan yang ada di pasal 16 Kitab Undang-Undang Hukum Dagang, yang menyebutkan bahwa firma adalah tiap-tiap persekutuan perdata yang didirikan untuk menjalankan suatu perusahaan dibawah satu nama bersama, maka sebagai persekutuan perdata atau firma dianut prinsip tanggung jawab renteng, jika KJPP tersebut adalah perorangan maka resiko hukum sepenuhnya dibebankan kepada pendirinya.

Berdasarkan konsep teori kepastian hukum menurut Gustav Radbruch, kepastian hukum adalah suatu peraturan dibuat dan diundangkan secara jelas, pasti dan logis, yang dimaksud jelas adalah tidak adanya kekaburan norma atau 
keraguan sedangkan logis adalah menjadi suatu sistem norma dengan norma yang lain sehingga tidak berbenturan atau menimbulkan konflik norma. Kepastian hukum memberikan pemberlakuan hukum yang jelas, tetap, konsisten dan konsekuen, yang pelaksanaannya tidak dapat dipengaruhi oleh keadaan yang bersifat subyektif (Radburch,et al,2006:6).Dari analisa bahan hukum ini ditemukan bahwa akta yang dipergunakan adalah akta dibawah tangan, sedangkan dalam teori kepastian hukum sudah tentu Akta Autentik menjadi pilihan utama, karena memenuhi unsur-unsur teori tersebut.Akta Autentik menjadi alat bukti yang sempurna, yaitu jika diajukan kedepan hakim sebagai alat bukti, maka hakim harus menerima dan menganggap isi yang tertulis dalam akta tersebut sungguhsungguh telah terjadi, dan hakim tidak boleh memerintahkan penambahan pembuktian.

Menurut Gustav Radbruch, yang juga seorang pelopor teori Rechtsidee, tujuan hukum pada umumnya adalah untuk mencapai keadilan (gerechmatigheid), kemanfaatan (rechtmatigheid), kepastian (doelmaghteid), ketiga hal tersebut adalah tujuan utama dari awal pembentukan, pelaksanaan dan penegakan aturan hukum. Tanpa adanya tujuan hukum maka peraturan yang dibuat menjadi siasia, tujuan hukum menjadi tolok ukur yang bersifat regulatif dan konstruktif, sehingga tanpa adanya tujuan hukum maka produk hukum yang dihasilkan akan kehilangan makna (Warassih, 2005 : 217). Terdapat beberapa teori dari tujuan hukum, antara lain (Erwin, 2011 : 179):

\section{1) Teori Etis}

Tujuan hukum adalah untuk mencapai keadilan, teori ini di pelopori oleh Aristoteles yang mengatakan bahwa tujuan hukum adalah memberikan hak yang dimiliki oleh seseorang.Hukum hanya ditentukan oleh keyakinan seseorang tentang mana yang adil dan mana yang tidak, keadilan berdasarkan teori etis dibagi lagi menjadi keadilan komulatif dan keadilan distributif. Keadilan komulatif memberikan keadilan dalam bentuk yang sama kepada 
semua orang, sedangkan keadilan distributif memberikan keadilan secara proporsional kepada setiap orang. Keadilan komulatif diberikan kepada semua orang secara merata, sedangkan keadilan distributif diberikan tergantung besar kecilnya jasa seseorang yang dilakukannya.

\section{2) Teori Utilitas}

Tujuan hukum adalah mencapai kemanfaatan tidak hanya kepada satu atau dua orang saja, namun kepada masyarakat sebagai keseluruhan.Teori ini dipelopori oleh Jeremy Bentham yang menyatakan bahwa tujuan hukum adalah untuk menghasilkan kemanfaatan dan kebahagiaan sebesar-besarnya bagi sebanyak-banyaknya orang. Teori ini mengutamakan kemanfaatan tanpa adanya unsur keadilan didalamnya dan apakah hukum tersebut baik atau buruk, maka Undang-Undang yang banyak memberikan kebahagiaan adalah Undang-Undang yang baik .

3) Teori Campuran

Dalam teori ini pelopornya adalah Apeldoorn, tujuan hukum adalah untuk mengatur tata tertib dalam masyarakat secara damai dan adil. Teori ini merupakan gabungan dari teori etis dan teori utilitas, sehingga tujuan hukum bukanlah hanya keadilan saja tetapi juga kemanfaatan, teori ini memperhatikan kepentingan seseorang dengan orang lain agar memperoleh haknya sebaik mungkin.

Maka berdasarkan teori tujuan hukum ini maka dapat dilihat dengan jelas perbandingan antara akta dibawah tangan dan akta autentik (akta notaris) berdasarkan tabel dibawah ini :

Tabel Perbandingan Akta Berdasar Teori Tujuan Hukum

\begin{tabular}{|c|c|c|c|}
\hline \multirow{4}{*}{ Akta Autentik (Akta Notaris) } & Teori Etis & Teori & Teori \\
\hline & Terpenuhi & Utilitas & Campuran \\
\hline & Ya/Tidak & Terpenuhi & Ya/Tidak \\
\hline & & Ya/Tidak & \\
\hline $\begin{array}{l}\text { Akta yang bentuknya ditentukan oleh } \\
\text { Undang-Undang. }\end{array}$ & Ya & $\mathrm{Ya}$ & $\mathrm{Ya}$ \\
\hline
\end{tabular}


$\begin{array}{llll}\text { Dibuat oleh dan dihadapan pejabat umum } & \text { Ya } & \text { Ya } & \text { Ya }\end{array}$ yang berwenang untuk itu ditempat dimana akta tersebut dibuat.

$\begin{array}{llllll}\text { Akta autentik adalah alat bukti yang } & \text { Ya } & \text { Ya } & \text { Ya }\end{array}$ sempurna.

\section{Akta Dibawah Tangan}

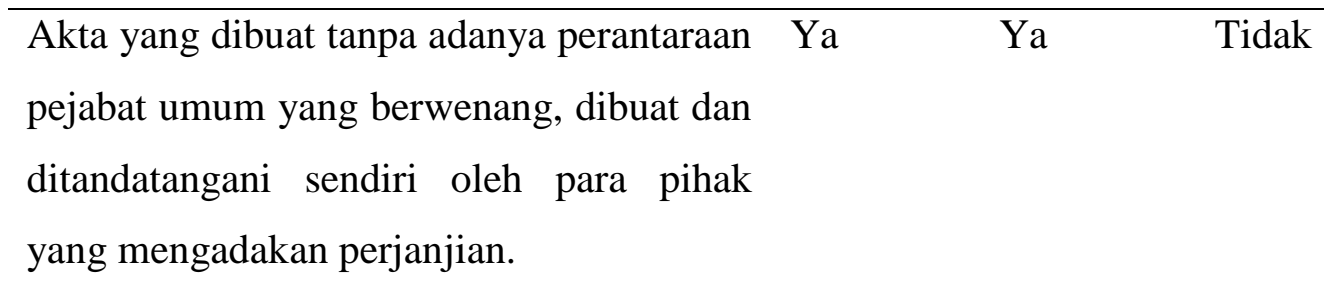

Selama para pihak yang menandatangani $\mathrm{Ya}$ Ya Tidak tidak menyangkal apa yang mereka tulis dalam isi akta tersebut, maka kekuatan pembuktiannya sama dengan akta auntentik.

\begin{tabular}{|c|c|}
\hline Selain dapat memberikan & luas terhadap KJPP.Keberadaan Akta \\
\hline kepastian hukum, Akta Notaris juga & Notaris yang juga \\
\hline dapat menunjukkan hak dan & merupakan \\
\hline kewajiban yang berimbang antara & merupakan \\
\hline Perusahaan Emiten dan KJPP, serta & sehingga keberadaan perikatan \\
\hline memungkinkan untuk di buat & tersebut dapat terdokumentasi dan \\
\hline pembatasan-pembatasan yang & terpelihara dengan baik sebagai dasar \\
\hline disepakati sejauh tidak bertentangan & kepastian hukum untuk menjamin \\
\hline dengan undang-undang & hak serta kewajiban para pihak \\
\hline mendasari terjadinya perikatan & dalam isi perikatan tersebut. \\
\hline tersebut. & Akibat hukum yang timbul dari \\
\hline $\begin{aligned} & \text { Akta } \text { Notaris berguna untuk } \\
& \text { mencegah terjadinya kemungkinan }\end{aligned}$ & $\begin{array}{l}\text { Akta Notaris sebagai perikatan } \\
\text { kerja antara KJPP } \\
\text { Perusahaan Emiten. }\end{array}$ \\
\hline
\end{tabular}
tuntutan tanggung jawab yang terlalu 


\begin{abstract}
Berdasarkan teori kepastian hukum Gustav Radbruch dengan adanya Akta Notaris akan memberikan kontribusi yang mendasar terhadap kepastian hukum dari perikatan antara Perusahaan Emiten dan KJPP, karena keadaan suatu peraturan dibuat dan diundangkan secara jelas, pasti dan logis, yang dimaksud jelas adalah tidak adanya kekaburan norma atau keraguan sedangkan logis adalah menjadi suatu sistem norma dengan norma yang lain sehingga tidak berbenturan atau menimbulkan konflik norma.
\end{abstract}

Kepastian hukum akan tercapai dengan adanya Akta Notaris bagi kedua belah pihak, dan pihak yang terdampak seperti masyarakat luas termasuk investor juga akan terlindungi, kerana Akta Notaris mampu memberikan pemberlakuan hukum yang jelas, tetap, konsisten dan konsekuen, yang pelaksanaannya tidak dapat dipengaruhi oleh keadaan yang bersifat subyektif sekalipun.

Akta Notaris memiliki ciri-ciri, bentuknya telah disesuaikan dengan Undang-Undang (Pasal 1868 KUHPedata Jo Pasal 1 ayat (7) UU
Nomor 30 tahun 2004), dibuat di hadapan pejabat umum yang berwenang (Pasal 1868 KUHPerdata), kekuatan pembuktian yang sempurna (Pasal 1870 KUHPerdata). Menurut Yahya Harahap kekuatan pembuktian yang melekat dalam akta auntentik (Akta Notaris) terdiri atas tiga kekuatan yaitu (Harahap,2005:566);

1) Kekuatan pembuktian luar, adalah melekatkan prinsip anggapan hukum bahwa setiap Akta Autentik harus dianggap benar sebagai Akta Autentik sampai pihak lawan mampu membuktikan sebaliknya.

2) Kekuatan pembuktian formil, berdasarkan Pasal 1871 KUHPerdata bahwa segala keterangan yang tertuang di dalamnya adalah benar diberikan dan disampaikan kepada pejabat yang membuatnya.

3) Kekuatan pembuktian materil, akibat hukum akta dikaitkan kekuatan pembuktian materil adalah apabila terdapat dua orang atau lebih, dan antara satu dengan yang lain saling memberi keterangan untuk dituangkan dalam akta, tindakan mereka itu menimbulkan akibat hukum sepanjang keterangan atau 
pernyataan itu bersesuaian, melahirkan persetujuan yang mengikat kepada mereka.

Akta Notaris tersebut juga merupakan dasar bagi Perusahaan Emiten yang akan menjadi perusahaan publik untuk menjalankan kewajiban terhadap keterbukaan informasi seperti yang tercantum dalam Pasal 1 angka 25 UUPM (Nasaruddin dkk, 2011:151). Perusahaan Emiten juga dituntut untuk dapat meningkatkan pertumbuhan perusahaan sehingga akan dapat meningkatkan citra perusahan dan harus mengikuti peraturan-peraturan yang ada dalam pasar modal mengenai kewajiban pelaporan (Nasaruddin,2011:215219).

Akibat hukum Akta Notaris bagi KJPP adalah menyatunya ketentuan peraturan perundang-undangan yang mengatur KJPP berserta isi perikatan yang dibuat bersama Perusahaan Emiten.Menurut Joni Emirzon, akibat hukum yang muncul adalah tanggung jawab hukum dari Profesi Penilai berdasarkan Kode Etik Penilai Indonesia terhadap integritas
Profesi Penilai (Emirzon, 2000:9091), antara lain;

1) KJPP harus cukup memiliki Penilai dengan keahlian khusus yang diperlukan, jika tidak mencukupi maka KJPP harus menolak pekerjaan tersebut.

2) KJPP harusnya berusaha untuk meningkatkan pengetahuan, keahlian dan ketrampilan penilaian.

3) KJPP harus membatasi kepentingan hanya kepada upah jasa yang menjadi haknya.

Terhadap Pelanggan Profesi Penilai;

1) Memberikan penilaian yang lengkap, teliti dan bertanggungjawab tanpa menghiraukan keinginan pelanggan yang sifatnya mengubah hasil penilaian yang obyektif, karena hubungannya bukan antara prinsipal dan agen.

2) Harus merahasiakan hasil penilaiannya kepada pihak manapun, karena laporan penilaian adalah milik pelanggan.

3) KJPP harus memberikan penjelasan kepada pelanggan mengenai luasnya ruang lingkup pekerjaan yang akan dilakukan, 
dan atas dasar ini KJPP dapat memberikan perkiraan upah jasanya.

Terhadap Masyarakat luas;

1) KJPP mempunyai tanggung jawab mutlak untuk tidak memberikan penilaian yang keliru, kekeliruan yang terjadi menjadi tanggung jawab mutlak KJPP.

2) KJPP wajib menjunjung tinggi tanggung jawabnya kepada masyarakat yang telah memberikan kepercayaan kepadanya untuk bertindak jujur dan obyektif dalam menjalankan profesinya.

3) Apabila pelanggan menggunakan laporan penilaian ini sebagai dasar tindakan-tindakan dari transaksi-transaksi, maka kejujuran dan obyektifitas laporannya wajib dijamin sekalipun berdampak kepada pihak lain selain pelanggan.

Tujuan hukum untuk mencapai keadilan dari sisi teori etis dapat dianalis bahwa Akta Notaris secara komulatif dapat memberikan keadilan dalam bentuk berimbang kepada para pihak dengan menuliskan semua hak dan tanggung jawab secara jelas, sedangkan keadilan distributif terjadi secara proporsional kepada para pihak dengan menujukkan besar kecilnya jasa para pihak sebagai prestasi dan hasil kerja sebagai kontraprestasinya.

Tujuan hukum lainnya adalah untuk mencapai kemanfaatan tidak hanya kepada para pihak saja satu atau dua orang saja, namun kepada masyarakat sebagai keseluruhan. Teori utilitas dapat dipenuhi dengan Akta Notaris dimaksud, karena dengan adanya Akta Notaris maka para pihakpun sepakat untuk memenuhi kewajibannya secara publik bukan lagi hanya untuk para pihak (private), karena Akta ini telah menjadi dokumen negara, dibuat oleh pejabat publik dan dengan tujuan agar mampu melindungi pasar saham serta kepentingan dan hak masyarakat secara luas, terutama selaku investor.

\section{Simpulan}

Berdasarkan hasil pembahasan tersebut diatas, maka dapat diambil kesimpulan sebagai berikut : 
1) Perikatan yang dipergunakan antara Perusahaan Emiten dan KJPP adalah akta dibawah tangan yaitu akta yang dibuat tanpa adanya perantaraan pejabat umum yang berwenang, melainkan dibuat dan ditandatangani sendiri oleh para pihak yang mengadakan perjanjian, akta ini biasa dipergunakan dari perikatanperikatan yang lahir dari perjanjian, bukan dari UndangUndang. Menurut Pasal 8 ayat (1) Undang-Undang Nomor 12 Tahun $2011 \quad$ Tentang Pembentukan Peraturan Perundang-Undangan disebutkan atau ditentukan bahwa suatu perbuatan atau tindakan hukum wajib dibuat dalam bentuk akta notaris, termasuk yang dibuat atau ditetapkan oleh Badan, Lembaga, atau Komisi yang setingkat yang dibentuk dengan Undang-Undang atau Pemerintah atas perintah Undang-Undang. Jadi keberlakuan Akta Notaris dari perikatan yang dilakukan oleh Perussahaan Emiten dan KJPP adalah suatu keharusan guna tercapainya kepastian hukum bagi Perusahaan Emiten, KJPP, dan masyarakat investor serta pasar modal secara umum.Perikatan yang dipergunakan selama ini antara Perusahaan Emiten dan KJPP dalam bentuk akta dibawah tangan sudah seharusnya di rubah dengan Akta Notaris, bahkan karena dalam ketentuan perundang-undangan pasar modal dan yang saling berhubungan lainya tidak dengan jelas mengatur ketentuan perikatan hubungan kerja antara Perusahaan Emiten dan KJPP. Akta Notaris mampu memberikan kekuatan pembuktian yang sempurna, sehingga dapat menjadi sarana penting untuk memberikan kepastian dan kekuatan hukum atas hubungan kerja antara kedua pihak tersebut.

2) Berdasarkan tujuan hukum pada umumnya untuk mencapai keadilan, kemanfaatan dan kepastian, maka tujuan utama dari awal pembentukan, pelaksanaan dan penegakan 
aturan hukum menjadi tolok ukur yang bersifat regulatif dan konstruktif, sehingga tanpa adanya tujuan hukum maka produk hukum yang dihasilkan akan kehilangan makna, sehingga Akta Notaris sebagai Akta Autentik yang sempurna sesuai ketentuan Pasal 1868 KUHPerdata, merupakan sarana utama untuk mencapai tujuan hukum yang dimaksud. Akta Notaris memberikan pemberlakuan hukum yang jelas, tetap, konsisten dan konsekuen, yang pelaksanaannya tidak dapat dipengaruhi oleh keadaan yang bersifat subyektif. Akta Autentik menjadi alat bukti yang sempurna yang artinya jika diajukan kedepan hakim sebagai alat bukti, maka hakim harus menerima dan menganggap isi yang tertulis dalam akta tersebut sungguh-sungguh telah terjadi, dan hakim tidak boleh memerintahkan penambahan pembuktian.Akta Notaris juga dapat menunjukkan hak dan kewajiban yang berimbang antara Perusahaan Emiten dan KJPP, serta memungkinkan untuk di buat pembatasan-pembatasan yang disepakati sejauh tidak bertentangan dengan undangundang yang mendasari terjadinya perikatan tersebut. Akta Notaris berguna untuk mencegah terjadinya kemungkinan tuntutan tanggung jawab yang terlalu luas terhadap KJPP serta keberadaan Akta Notaris yang juga menjadi Protokol Notaris sebagai dokumen negara, mengakibatkan keberadaan perikatan tersebut dapat terdokumentasi dan terpelihara dengan baik sebagai dasar kepastian hukum untuk menjamin hak serta kewajiban para pihak dalam isi perikatan tersebut.

3) Akta Notaris merupakan kontribusi yang mendasar terhadap kepastian hukum dari perikatan antara Perusahaan Emiten dan KJPP, dengan adanya Akta Notaris yang dibuat berdasarkan peraturan dan diundangkan secara jelas, pasti dan logis, maka akibat hukum yang akan ditimbulkan terhadap 
kewajiban dan hak antara

Perusahaan Emiten dan KJPP akan tercapai, dan pihak yang terdampak seperti masyarakat luas termasuk investor juga pasar modal akan terlindungi, kerana Akta Notaris mampu memberikan pemberlakuan hukum yang jelas, tetap, konsisten dan konsekuen, yang pelaksanaannya tidak dapat dipengaruhi oleh keadaan yang bersifat subyektif sekalipun. Akta Notaris penting untuk dipergunakan dalam perikatan antara Perusahaan Emiten dan KJPP, karena dapat memberikan keadilan yang berimbang kepada para pihak dengan menuliskan semua hak dan tanggung jawab secara jelas, yang terdistribusi secara proporsional dengan menujukkan besar kecilnya jasa para pihak sebagai prestasi dan hasil kerja sebagai kontraprestasinya. Akibat hukum lainnya dari Akta Notaris adalah untuk mencapai kemanfaatan tidak hanya kepada para pihak saja, namun kepada masyarakat sebagai keseluruhan, sehingga pihak Perusahaan Emiten dan KJPP akan melaksakan tindakantindakan atas profesinya dengan penuh kepatuhan dan baik.

\section{Daftar Pustaka}

Buku :

Atre, B.R., 2001,Legislative Drafting, Prinsiples and Tecnhniques, New Delhi, Universal Law Publishing, Co, Pvt, Ltd.

Dyah Ochtorina Susanti, A'an Efendi, 2013,Penelitian Hukum (Legal Research), Jakarta: Sinar Grafika.

Esmi Warassih, 2005, Pranata Hukum Sebuah Telaah Sosiologi, Semarang, Suryadaru Utama.

Habib Adjie, 2015, Penafsiran Tematik Hukum Notaris Indonesia, Bandung, PT.Refika Aditama.

I Made Pasek Diantha, 2016,Metodologi Penelitian Hukum Normatif, Dalam Justifikasi Teori Hukum, Jakarta: Prenada Media Group.

Joni Emirzon, 2000, Aspek-Aspek Hukum Perusahaan Jasa Penilai, Jakarta, PT.Gramedia Pustaka Utama.

Kartini Muljadi, Gunawan Widjaja, 2014, Perikatan Yang Lahir 
Dari Perjanjian, Jakarta, PT. RajaGrafindo Persada.

M. Yahya Harahap, 2005, Hukum Acara Perdata Indonesia, Jakarta, PT. Sinar Grafika.

M.Irsan Nasarudin, Indra Surya, Ivan Yustiavandana, Arman Nefi, Adiwarman, 2011,Aspek Hukum Pasar Modal Indonesia, Jakarta: Kencana Predana Media Group.

Muh. Erwin, 2011,Filsafat Hukum : Refleksi Kritis Terhadap Hukum, Jakarta, PT. Rajawali Press.

Masyarakat Profesi Penilai Indonesia (MAPPI), 2013, Kode Etik Penilai Indonesia Dan Standar Penilaian Indonesia, Jakarta, CV. Gelora Karya Bharata.

Peter Mahmud Marzuki, 2009, Pengantar Ilmu Hukum, Jakarta, Kencana Prenada Media Group.

Rusdin, 2006, Pasar Modal, Teori, Masalah dan Kebijakan Dalam Praktik, Bandung: Alfabeta.

R.Soeroso,2011,Perjanjian Dibawah Tangan, Pedoman Praktis Pembuatan dan Aplikasi Hukum, Jakarta: Sinar Grafika.

Tjiptono Darmadji, Hendy M.Fakhruddin, 2012, Pasar Modal di Indonesia
Pendekatan Tanya Jawab, Jakarta: Salemba Empat.

Tavinayati, Yulia Qamariyanti, 2009, Hukum Pasar Modal Indonesia, Jakarta: Sinar Grafika.

\section{Jurnal :}

Bapepam, 1996, Cetak Biru Pasar Modal Indonesia, Departemen Keuangan Republik Indonesia, Jakarta.

Gustav Radbruch, Bonnie Litschewski Paulson and Stanley L. Paulson, 2006, Statutory Lawlessness and Supra-Statutory Law (1946), Oxford Journal of Legal Studies, Vol. 26, No. 1 , Oxford University Press.

\section{Peraturan Perundang-undangan :}

Kitab Undang-Undang Hukum Perdata.

Undang-Undang Nomor 8 tahun 1995 Tentang Pasar Modal.

Undang-Undang Nomor 21 Tahun 2011 Tentang Otoritas Jasa Keuangan.

Peraturan Menteri Keuangan Nomor 125/PMK.01/2008 Tanggal 3 September 2008 Tentang Jasa Penilai Publik.

Keputusan Menteri Perdagangan Nomor 161/KP/VI/77 tanggal 7 Juli 1977 Tentang Ketentuan Perizinan Usaha Jasa Penilaian. 
Keputusan Menteri Keuangan

Nomor 57/KMK.017/1996

Tentang Jasa Penilai Publik.

Keputusan Bersama Antara Menteri

Perindustrian dan

Perdagangan dan Menteri

Keuangan tanggal 1 Juli

2004 Nomor :

423/MPP/Kep/7/2004

327/KMK.06/2004 Tentang

Pelimpahan Tugas Dan

Wewenang Menteri

Perindustrian Dan

Perdagangan Mengenai

Pembinaan Dan

Pengawasan Usaha Jasa

Penilai Kepada Menteri

Keuangan.

Peraturan Menteri Keuangan Nomor

101/PMK.01/2014 Tentang

Penilai Publik.

Surat Edaran Bank Indonesia Nomor 15/40/DKMP tahun 2013.

Keputusan Ketua Badan Pengawas Pasar Modal dan Lembaga Keuangan Nomor : KEP620/BL/2011 Tentang Pedoman Penilaian Dan Penyajian Laporan Penilaian Aset Tak Berwujud.

Keputusan Ketua Badan Pengawas Pasar Modal dan Lembaga Keuangan Nomor : KEP196/BL/2012 Tentang Pedoman Penilaian Dan Penyajian Laporan Penilaian Usaha Di Pasar Modal 